\title{
Quality of conilon coffee dried on a concrete terrace in a greenhouse with early hulling
}

\section{Qualidade do café conilon, seco em terreiro de estufa com beneficiamento antecipado}

\author{
Fábio Luiz Partelli ${ }^{1 *}$; Ozílio Partelli²; Akila Sirilo Partelli; \\ Flávio Meira Borém³ ${ }^{3}$ José Henrique da Silva Taveira ${ }^{4}$
}

\begin{abstract}
The time spent in coffee drying is quite important for keeping the product quality and therefore choosing the appropriate method to be used. This study was performed to quantify the decrease in drying time as a result of early hulling of conilon coffee (Coffea canephora) dried on a concrete terrace in a greenhouse, as well as to determine the quality of the dried coffee. The coffee was harvested at more than $80 \%$ ripe fruits and immediately placed on concrete terraces in greenhouses for drying. The parcels were hulled when $22 \%, 19 \%, 16 \%$ and $13 \%$ (wb) moisture levels were reached. Then, the parcels hulled at $22 \%, 19 \%$ and $16 \%$ moisture were returned to the greenhouse until they reached the desired moisture level of $13 \%(\mathrm{wb})$. The time spent on drying was quantified, and coffee quality was assessed through sensory, chemical and physiological analyses. This procedure was performed in four distinct periods during the harvest, and four repetitions were performed in blocks. The F (ANOVA) and Tukey (at 5\% of probability) tests were performed to compare the evaluated characteristics among groups. The coffee hulled at $22 \%(\mathrm{wb})$ moisture content presented a considerably shorter drying time (6 days shorter) than the coffee hulled at $13 \%(\mathrm{wb})$ moisture content. The early hulling of conilon coffee did not affect the final quality. Thus, early hulling is a practical and significantly favorable technique for coffee farmers because it decreases drying time and improves the use of terrace space without diminishing coffee quality.
\end{abstract}

Key words: Coffea canephora, robusta, drying, electrical conductivity, reducing sugars

\section{Resumo}

O tempo despendido na secagem é fundamental para manter a qualidade do produto e escolher o procedimento de secagem a ser adotado. Esse trabalho teve como objetivo quantificar a redução do tempo de secagem com beneficiamento prévio do café conilon (Coffea canephora) em terreiro de estufa, bem como avaliar a qualidade dos grãos secos. O café conilon foi colhido com mais de $80 \%$ de frutos maduros e colocados, simultaneamente, em terreiros de estufas. Assim, as parcelas foram beneficiadas no momento em que atingiram $22 \%, 19 \%, 16 \%$ e $13 \%$ de umidade (bu). As parcelas com $22 \%, 19 \%$ e $16 \%(\mathrm{bu})$, foram levadas de volta ao terreiro até que atingissem o nível de umidade ideal de $13 \%$ (bu). O tempo de secagem foi quantificado e a qualidade do produto avaliada através análise sensorial, química e fisiológica. $\mathrm{O}$ trabalho foi realizado em blocos ao acaso, com quatro repetições, e

\footnotetext{
${ }^{1}$ Eng $^{\circ}$ Agr $^{\circ}$, Dr. Prof., Dept ${ }^{\circ}$ de Ciências Agrárias e Biológicas, Universidade Federal do Espírito Santo, UFES, São Mateus, ES. Brasil.E-mail: partelli@yahoo.com.br

2 Farmer, Vila Valério, ES, Brasil. E-mail: juliapartelli@hotmail.com

${ }^{3}$ Eng $^{\circ}$ Agr $^{\circ}$, Dr. Prof., Dept ${ }^{\circ}$ de Engenharia Agrícola, Universidade Federal de Lavras, UFLA, Lavras, MG, Brasil. E-mail: flavioborem@deg.ufla.br

${ }^{4}$ Eng $^{\circ}$ Agr $^{\circ}$, Dr. Pós-Doutorado, Dept ${ }^{\mathrm{o}}$ de Engenharia Agrícola, UFLA, Lavras, MG, Brasil. E-mail: henriquetaveira@yahoo.com.br

* Author for correspondence
} 
os resultados submetidos ao teste F (ANOVA) e teste de média (Tukey a 5\% de probabilidade). Houve diminuição de 6 dias na secagem do café beneficiado a 22\% de umidade, comparado ao café beneficiado a $13 \%$. O beneficiamento prévio do café conilon não afetou a qualidade final. Assim, conclui-se que o beneficiamento prévio do café com $22 \%$ (bu), com posterior secagem até atingir $13 \%$ é uma prática que favorece de maneira significativa o cafeicultor, pois diminui o tempo de secagem e maximiza o uso de área no terreiro, sem perder qualidade do produto.

Palavras-chave: Coffea canephora, robusta, secagem, condutividade elétrica, açúcares redutores

\section{Introduction}

Conilon coffee (Coffea canephora) is one of the major species of the genus Coffea and is of great economic and social importance for Brazil and the world. Approximately $35 \%$ of the coffee produced in Brazil and more than $34 \%$ of the coffee marketed in the world is conilon coffee, while the remainder is arabica (C. arabica) (ICO, 2012). In 2011, the coffee market comprised $3.4 \%$ of all Brazilian exports, corresponding to more than 8,700 million dollars (MDICE, 2012). For many years, conilon coffee has been added to arabica coffee to enhance its flavor for the production of soluble coffee, justifying its industrial production in Brazil and worldwide (MORAIS et al., 2009). Recently, this practice has been intensified, and there are several good of conilon/arabica coffee blends available.

It is known that coffee flavor and aroma are strictly related to the chemical composition of the fruit (ESTEBAN-DÍEZ; GONZÁLEZ-SÁIZ; PIZARRO, 2004; RIBEIRO; FERREIRA; SALVA, 2011), and they depend on the complexity of more than 800 volatile compounds present in the grains (FRANCA et al., 2005). These characteristics are influenced by climate and soil conditions, coffee species and variety, crop management, harvest time, type of postharvest hulling, and drying and storage conditions (ESTEBAN-DÍEZ et al., 2007; FRANCA et al., 2005; MONTEIRO; FARAH, 2012; SIQUEIRA; ABREU, 2006). Within this context, drying is one of the key steps of postharvest coffee processing. Appropriate drying contributes to the preservation of the physiological characteristics of the coffee and guarantees a longer storage time (GARCIA et al., 2004). Moreover, improperly performed drying may damage the grain quality, causing undesirable physical, chemical and sensory changes (BORÉM et al., 2008).

Physiological analyses have been an efficient tool for separating coffee seeds into different quality levels (COSTA; CARVALHO, 2006) due to their correlation with the integrity of cell membranes. Higher values of potassium leaching and electrical conductivity are observed in coffees with more physiological damage and worse beverage quality. This occurs in coffees dried under higher temperatures (MARQUES et al., 2008).

Drying is one of the key stages that can overtax the costs of coffee production. The time spent on this step and the coffee quality are the fundamental factors for the choice of coffee drying procedure. Significantly reducing the drying time while maintaining coffee quality is fundamental for the best use of the drying structure and labor force and consequently for the profitability of the coffee producer. Thus, the aim of this study was to quantify and relate the reduction of drying time of early hulling of conilon coffee in terraced greenhouses with the final quality of the grains.

\section{Materials and Methods}

The experiment was conducted in Vila Valério, in northern Espírito Santo, Brazil. The conilon coffee was harvested at more than $80 \%$ ripe fruits and placed in concrete terraces with a transparent plastic cover (terrace in a greenhouse, hangar type). The moisture of coffee was systematically monitored posteriorly using a moisture measurer, and when coffee reached 22\%, 19\%, 16\% and $13 \%$ moisture, it was sent to a coffee peeler to be hulled. The coffee hulled at $22 \%, 19 \%$ and $16 \%$ of 
moisture was returned to the terrace until it reached $13 \%$ moisture. This procedure was performed in four distinct periods during the harvest, and four repetitions were performed in blocks.

The time required for the full drying of the coffee was quantified (before and after hulling). The sensory quality of the beverage (cup test/taste) was evaluated by a company that specializes in conilon cup tests using criteria established by the Coffee Quality Institute (CQI, 2012).

Samples of coffee were tested for electrical conductivity and potassium leaching as described by Krzyzanowski, França Neto and Henning (1991) and Malta, Pereira and Chagas (2005), total titratable acidity and total reducing sugars using the procedures described by AOAC (1997) and soluble solids in a benchtop refractometer.
The F (ANOVA) and Tukey (at $5 \%$ of probability) tests were performed to compare the evaluated characteristics among groups (SILVA, 2014).

\section{Results and Discussion}

Early hulling of conilon coffee reduced the drying time in a greenhouse terrace by more than six days when hulled at 22\% moisture (Table 1). The average gain in drying time was approximately two days among treatments. Faster drying occurred due to the absence of pericarp, a natural barrier to the exchange of heat and water. Therefore, the area of the terrace may be reduced, as can the labor force required for the drying of the same amount of coffee per crop, allowing a significant economy of resources and work force.

Table 1. The mean values of total time spent for drying of coffee hulled at different moisture and the associated quality (cup test). Vila Valério - ES, Brazil.

\begin{tabular}{cccc}
\hline Hulling & Drying time (days) & Quality scale Grade $^{1}$ & Quality scale Type $^{1}$ \\
\hline $22 \%$ & $7.20 \mathrm{a}$ & $73.31 \mathrm{a}$ & Very good \\
$19 \%$ & $9.21 \mathrm{~b}$ & $75.00 \mathrm{a}$ & Very good \\
$16 \%$ & $11.00 \mathrm{c}$ & $75.06 \mathrm{a}$ & Very good \\
$13 \%$ & $13.25 \mathrm{~d}$ & $75.50 \mathrm{a}$ & Very good \\
\hline $\mathrm{CV}(\%)$ & 7.92 & 2.48 & - \\
\hline
\end{tabular}

Means followed by the same letter were not significantly different (5\% probability, Tukey's test).

${ }^{1}$ Quality scale used by Coffee Quality Institute.

$\mathrm{CV}$, coefficient of variation.

Source: Elaboration of the authors.

Studies performed by Kouadio et al. (2012) using robusta coffee showed that longer exposure in terraces during drying is associated with greater susceptibility to fungi and ochratoxin. Moreover, the coffee becomes more acidified and degraded over time. This suggests that early hulling can help prevent these problems by reducing the time that the coffee must spend in the terrace.

Despite of the early removal of the pericarp, the quality of beverage was not reduced significantly (Table 1), and all treatments received a mean grade superior to 73, considered very good by the Coffee Quality Institute (CQI, 2012).

In addition to the advantages mentioned, the use of a greenhouse terrace did not require night work and did not pollute the environment. This arrangement may also be used to securely and efficiently dry other products, such as black pepper, corn, beans, or cocoa, among others.

The content of soluble solids, electrical conductivity and titratable acidity were equal in all treatments (Table 2). Potassium leaching was 
lowest in coffee hulled at $22 \%$ moisture, tending to increase as moisture decreases. These results indicate that early hulling did not negatively affect the coffee quality, suggesting that it may be a more efficient way to achieve the desired characteristics.

Table 2. Mean values of electrical conductivity, potassium leaching, total titratable acidity and soluble solids after total drying in coffee hulled at different moisture. Vila Valério - ES, Brazil.

\begin{tabular}{|c|c|c|c|c|}
\hline Hulling & Soluble solids (\%) & $\begin{array}{l}\text { Electrical conductivity } \\
\left(\mu \mathrm{S} \mathrm{cm}^{-1} \mathrm{~g}^{-1}\right)\end{array}$ & $\begin{array}{c}\text { Potassium } \\
\text { leaching }\end{array}$ & $\begin{array}{l}\text { Total titratable acidity } \\
\left(\mathrm{NaOH} 0,1 \mathrm{~N} 100 \mathrm{~g}^{-1}\right)\end{array}$ \\
\hline $22 \%$ & $1.31 \mathrm{a}$ & $56.68 \mathrm{a}$ & $15.48 \mathrm{a}$ & $238.12 \mathrm{a}$ \\
\hline $19 \%$ & $1.30 \mathrm{a}$ & $79.19 \mathrm{a}$ & $17.48 \mathrm{ab}$ & $212.50 \mathrm{a}$ \\
\hline $16 \%$ & $1.21 \mathrm{a}$ & $69.61 \mathrm{a}$ & $18.83 \mathrm{ab}$ & $228.75 a$ \\
\hline $13 \%$ & $1.29 \mathrm{a}$ & $86.28 \mathrm{a}$ & $23.56 \mathrm{~b}$ & $213.12 \mathrm{a}$ \\
\hline $\mathrm{CV}(\%)$ & 6.41 & 20.87 & 18.50 & 14.44 \\
\hline
\end{tabular}

Means followed by the same letter were not significantly different ( $5 \%$ probability, Tukey's test).

$\mathrm{CV}$, coefficient of variation.

Source: Elaboration of the authors.

The best coffees are those with the lowest values of potassium leaching, electrical conductivity and acidity (BORÉM etal., 2008; COSTA; CARVALHO, 2006; MARQUES et al., 2008; RODRIGUES et al., 2007; SIQUEIRA; ABREU, 2006). Therefore, it is suggested that early hulling did not affect the cell membrane integrity of the conilon coffee and further did not favor fermentation, degradation or other characteristics associated with moisture.

Malta, Pereira and Chagas (2005) reported that black, sour and green beans exhibit higher values of electrical conductivity and potassium leaching, and thus poorer quality, compared with samples without defects. This also suggests that early hulling did not favor the production of coffee with these defects because the early-hulled coffee presented equal or lower values of electrical conductivity and potassium leaching than later-hulled coffee (Table 2). According to Bandeira et al. (2009), green and green black coffee beans contain chemical compounds that are not found in higher quality coffees, which may be associated with the lower quality of the product. They also exhibited lower quality, undesirable acidity and oxidation (FARAH et al., 2006).
The index of acidity has a major influence on coffee sensory values (SIQUEIRA; ABREU, 2006) and may be considered pleasant to taste or not. Higher values of acidity, as well as potassium leaching, may be related to fermentation and/or degradation in the coffee grains (BORÉM et al., 2008; RODRIGUES et al., 2007), which decrease the beverage quality. Higher contents of sugar in coffee grains are always desirable (FARAH; DONANGEL, 2006) because sugars take part in important chemical reactions that occur during roasting, such as the Maillard reaction and/or the caramelization that produces the compounds responsible for the color, flavor and aroma of the beverage (CAMPA et al., 2004). However, this depends on the species, the site of coffee growth, the maturation stage of the fruits (CAMPA et al., 2004) and postharvest processes (LOPEZ et al., 2000). Drying has been highlighted as one of the main causes of changes in the quantity of sugar in the grains. Borém et al. (2006) and Marques et al. (2008) observed that the amount of reducing sugars decreases as temperature increases.

Early hulling did not alter the content of reducing, non-reducing and total sugars (Table 3). Reducing sugars react with amino acids through the Maillard reaction, producing undesirable compounds 
(BORÉM et al., 2006; FARAH; DONANGEL, 2006). Generally, higher contents of total and nonreducing sugars are found in higher-quality drinks (PINTO; FERNANDES; PIRES, 2001), which are responsible for the production of a caramel flavor, providing a sweetness to the drink (ABRAHÃO et al., 2009). The reducing sugar content generally decreases with the temperature used for drying (BORÉM et al., 2006; MARQUES et al., 2008), but this was not affected by the early hulling.

Table 3. Mean values of reducing, non-reducing and total sugars after total drying in coffee hulled at different moisture. Vila Valério - ES, Brazil.

\begin{tabular}{cccc}
\hline Hulling & Reducing sugars (\%) & Non-reducing sugars (\%) & Total sugars (\%) \\
\hline $22 \%$ & $0.52 \mathrm{a}$ & $4.30 \mathrm{a}$ & $4.82 \mathrm{a}$ \\
$19 \%$ & $0.45 \mathrm{a}$ & $4.48 \mathrm{a}$ & $4.93 \mathrm{a}$ \\
$16 \%$ & $0.49 \mathrm{a}$ & $4.31 \mathrm{a}$ & $4.80 \mathrm{a}$ \\
$13 \%$ & $0.54 \mathrm{a}$ & $3.88 \mathrm{a}$ & $4.42 \mathrm{a}$ \\
\hline CV $(\%)$ & 31.1 & 13.78 & 11.52 \\
\hline
\end{tabular}

Means followed by the same letter were not significantly different ( $5 \%$ probability, Tukey's test).

$\mathrm{CV}$, coefficient of variation.

Source: Elaboration of the authors.

\section{Conclusion}

The early hulling of conilon coffee decreases the drying time in a greenhouse terrace and does not alter the beverage quality. This offers a significant advantage for coffee producers because it optimizes the use of terrace area and work force.

\section{Acknowledgements}

The authors thank Conilon Brasil for performing the sensory analyses and the Universidade Federal do Espírito Santo (UFES), Universidade Federal de Lavras the Metalúrgica Fardin for partial support of this work.

\section{References}

ABRAHÃO, A. A.; PEREIRA, R. G. F. A.; BORÉM, F. M.; REZENDE, J. C.; BARBOSA, J. C. Classificação física e composição química do café submetido a diferentes tratamentos fungicidas. Coffee Science, Lavras, v. 4, n. 2, p. 100-109, 2009.

ASSOCIATION OF OFFICIAL ANALYTICAL CHEMISTS - AOAC. Official methods of analysis of AOAC. $3^{\text {th }}$ ed. Gaitherburg: AOAC, 1997.
BANDEIRA, R. D. C. C.; TOCI, A. T.; TRUGO, L. C.; FARAH, A. Composição volátil dos defeitos intrínsecos do café por CG/em-Headspace. Química Nova, São Paulo, v. 32, n. 2, p. 309-314, 2009.

BORÉM, F. M.; CORADI, P. C.; OLIVEIRA, J. A.; SAATH, R. Qualidade do café natural e despolpado após secagem em terreiro e com altas temperaturas. Revista Ciência e Agrotecnologia, Lavras, v. 32, n. 5, p. 16091615, 2008.

BORÉM, F. M.; RIBEIRO, D. M.; PEREIRA, R. G. F. A.; ROSA, S. D. V. F.; MORAIS, A. R. Qualidade do café submetido a diferentes temperaturas, fluxos de ar e períodos de pré-secagem. Coffee Science, Lavras, v. 1, n. 1, p. 55-63, 2006.

CAMPA, C.; BLLESTER, J. F.; DOULBEAU, S.; DUSSERT, S.; HAMON, S.; NOIROT, M. Trigonelline and sucrose diversity in wild Coffea species. Food Chemestry, Washington, v. 88, n. 1, p. 39-43, 2004.

COFFEE QUALITY INSTITUTE - CQI. SCAA Standards and Protocols. Aliso Viego: Coffee Quality Institute, 2012. Available at: $<$ http://www.coffeeinstitute. org/resources/scaa-standards-and-protocols $>$. Accessed at: 29 oct. 2012.

COSTA, P. S. C.; CARVAlhO, M. L. M. Teste de condutividade elétrica individual na avaliação da qualidade fisiológica de sementes de café (Coffea arabica L.). Revista Ciência e Agrotecnologia, Lavras, v. 30, n. 1, p. 92-96, 2006. 
ESTEBAN-DÍEZ， I.; GONZÁLEZ-SÁIZ， J. M.; PIZARRO, C. Prediction of sensory properties of espresso from roasted coffee samples by near-infrared spectroscopy. Analytica Chimica Acta, London, v. 525, n. 2, p. 171-182, 2004.

ESTEBAN-DÍEZ, I.; GONZÁLEZ-SÁIZ, J. M.; SÁENZ-GONZÁLEZ, C.; PIZARRO, C. Coffee varietal differentiation based on near infrared spectroscopy. Talanta, Washington, v. 71, n. 1, p. 221-229, 2007.

FARAH, A.; DONANGEL, C. M. Phenolic compounds in coffee. Brazilian Journal of Plant Physiology, Viçosa, v. 18, n. 1, p. 23-36, 2006.

FARAH, A.; MONTEIRO, M. C.; CALADO, V.; FRANCA, A. S.; TRUGO, L. C. Correlation between cup quality and chemical attributes of Brazilian coffee. Food Chemistry, Washington, v. 98, n. 2, p. 373-380, 2006.

FRANCA, A. S.; OLIVEIRA, L. S.; MENDONÇA, J. C. F.; SILVA, X. A. Physical and chemical attributes of defective crude and roasted coffee beans. Food Chemistry, Washington, v. 90, n. 1, p. 89-94, 2005.

GARCIA, D. C.; BARROS, A. C. S. A.; PESKE, S. T.; MENEZES, N. L. A secagem de sementes. Ciência Rural, Santa Maria, v. 34, n. 2, p. 603-608, 2004.

INTERNATIONAL COFFEE ORGANIZATION - ICO. Statistics. London: International Coffee Organization, 2012. Available at: $<\mathrm{http}: / / \mathrm{www}$.ico.org/trade statistics. asp >. Accessed at: 7 nov. 2012.

KOUADIO, I. A.; KOFFI, L. B.; NEMLIN, J. G.; DOSSO, M. B. Effect of robusta (Coffea canephora P.) coffee cherries quantity put out for sun drying on contamination by fungi and Ochratoxin A (OTA) under tropical humid zone (Côte d'Ivoire). Food and Chemical Toxicology, Andover, v. 50, n. 6, p. 1969-1979, 2012.

KRZYZANOWSKI, F. C.; FRANÇA NETO, J. B.; HENNING, A. A. Relatos dos testes de vigor disponíveis as grandes culturas. Informativo Abrates, Viçosa, v. 1, n. 2, p. 15-50, 1991.

LOPEZ, L. M. V.; PEREIRA, R. G. F. A.; MENDES, A. N. G.; VILELA, E. R.; CARVALHO, V. D Avaliação da qualidade de grãos de diferentes cultivares de cafeeiro (Coffea arabica L.). Revista Brasileira de Armazenamento, Viçosa, n. 1, p. 3-8, 2000. Especial café.

MALTA, M. R.; PEREIRA, R. G. F. A.; CHAGAS, S. J. R. Condutividade elétrica e lixiviação de potássio do exsudato de grãos de café: alguns fatores que pode influenciar essas avaliações. Revista Ciência e
Agrotecnologia, Lavras, v. 29, n. 5, p. 1015-1020, 2005.

MARQUES, E. R.; BORÉM, F. M.; PEREIRA, R. G. F. A.; BIAGGIONI, M. A. M. Eficácia do teste de acidez graxa na avaliação da qualidade do café arábica (Coffea arabica L.) submetido a diferentes períodos e temperaturas de secagem. Revista Ciência e Agrotecnologia, Lavras, v. 32, n. 5, p. 1557-1562, 2008.

MINISTÉRIO DO DESENVOLVIMENTO, INDÚSTRIA E COMÉRCIO EXTERIOR - MDICE. Balança comercial brasileira - dados consolidados, 2011. Brasília: MDICE, 2012. Available at: <http:// www.desenvolvimento.gov.br/sitio/interna/interna. php?area $=5 \&$ menu $=571>$. Accessed at: 7 jun. 2012.

MONTEIRO, M. C.; FARAH, A. Chlorogenic acids in Brazilian Coffea arabica cultivars from various consecutive crops. Food Chemistry, Washington, v. 134, n. 1, p. 611-614, 2012.

MORAIS, S. A. L.; AQUINO, F. J. T.; NASCIMENTO, P. M.; NASCIMENTO, E. A.; CHANG, R. Compostos bioativos e atividade antioxidante do café conilon submetido a diferentes graus de torra. Química Nova, São Paulo, v. 32, n. 2, p. 327-331, 2009.

PINTO, N. A. V. D.; FERNANDES, S. M.; PIRES, T. C. Avaliação dos polifenóis e açúcares em padrões de bebida do café torrado tipo expresso. Revista Brasileira de Agrociência, Pelotas, v. 7, n. 3, p. 193-195, 2001.

RIBEIRO, J. S.; FERREIRA, M. M. C.; SALVA, T. J. G. Chemometric models for the quantitative descriptive sensory analysis of Arabica coffee beverages using near infrared spectroscopy. Talanta, Washington, v. 83, n. 4, p. 1352-1358, 2011.

RODRIGUES, C. I.; MARTA, L.; MAIA, R.; MIRANDA, M.; RIBEIRINHO, M.; MÁGUAS, C. Application of solid-phase extraction to brewed coffee caffeine and organic acid determination by UV/HPLC. Journal of Food Composition and Analysis, San Diego, v. 20, n. 5, p. 440-448, 2007.

SILVA, F. A. S. Assistat: statistical assistance. versão 7.6 beta. Campina Grande: Universidade Federal de Campina Grande, 2014. Available at: <http://www.assistat.com/ indexi.html>. Accessed at: 22 abr. 2014.

SIQUEIRA, H. H.; ABREU, C. M. P. Composição físicoquímica e qualidade do café submetido a dois tipos de torração e com diferentes formas de processamento. Revista Ciência e Agrotecnologia, Lavras, v. 30, n. 1, p. 112-117, 2006. 